\title{
BIO-BASED CIRCULAR ECONOMY IN EUROPEAN NATIONAL AND REGIONAL STRATEGIES
}

\author{
SUSANNA VANHAMAKI ${ }^{1}$, KATERINA MEDKOVA ${ }^{1}$, APOSTOLOS MALAMAKIS ${ }^{2}$, STAMATIA \\ KONTOGIANNI $^{2}$, ELEONORA MARISOVA ${ }^{3}$, DAVID HUISMAN DELLAGO ${ }^{1} \&$ NICOLAS $^{2}$ \\ MOUSSIOPOULOS ${ }^{2}$ \\ ${ }^{1}$ Lahti University of Applied Sciences, Finland. \\ 2 Aristotle University of Thessaloniki, Greece. \\ ${ }^{3}$ Slovak University of Agriculture in Nitra, Slovakia.
}

\begin{abstract}
In circular economy (CE), the value of products and materials is maintained for as long as possible. What has previously been considered waste is now a resource that can be reused and reintroduced to the production cycle. Therefore, waste management of both technical and bio-based waste streams plays a central role in the transition towards CE. In bioeconomy, the materials are to a certain extent circular by nature. However, biomaterials may also be used in a rather linear way. According to the European Commission, the transition towards CE needs to be supported on local, regional and national levels. Thus, to enhance sustainability and get the full potential out of bioeconomy, the CE principles should be applied to reach bio-based CE. This paper presents the results of a qualitative assessment that was carried out in Finland, Spain, Slovakia, Greece, Romania and France. Selected national and regional strategies were identified, compared and analyzed from the perspective of CE and bio-based CE. At the time of the study, the added value of $\mathrm{CE}$ was recognized in most of the national and regional level strategies studied, through objectives concerning e.g. waste management or bioenergy. Bio-based CE was hardly ever included as a term but circularity aspects were referred to for example through biowaste management. Waste management appears to be the main driver in the transition towards CE. This is evident also in the case presented from Slovakia. Yet, in order for CE to become an integral part of national and regional policies, a more comprehensive understanding of the CE mechanisms should be achieved. Supported actions on both small and large-scale are needed. The research is partly an outcome of the ongoing Interreg Europe project BIOREGIO, where the bio-based circular economy is boosted through a transfer of expertise about best practices, aiming at changing regional policies to support bio-based CE.

Keywords: bio-based materials, circular economy, national strategies, regional strategies.
\end{abstract}

\section{INTRODUCTION}

Sustainability is the capability to remain productive for an indefinite period [1]. This is reflected ecologically in the natural systems, where resources and diversity stay constant and available for future generations to come [2]. Defined as a common goal of the United Nations [3], sustainable development encompasses environmental protection in balance with social and financial sustainability.

Sustainability, in terms of economic models, is defined as the achievement of current needs without directly or indirectly compromising the needs of future generations [4]. This is closely linked to Circular Economy (CE) [5], [6]. CE differs from an 'unsustainable' traditional linear economy by introducing a cyclical flow model. $\mathrm{CE}$ is a regenerative industrial system, which aims at elimination of waste through closing material loops [7], [8]. According to Ghisellini et al. [5], CE promotes an environmentally sound use of resources and the idea of new business models. According to the definition by the European Commission [9], CE aims at enabling the maximization of resource efficiency and minimization of waste production, benefiting the environment and tackling production costs at the same time. The technical approach to CE focuses on the recycling, reuse and prolongation of a product's lifespan 
before utilizing the material whilst the aim of the biological cycle is to keep the nutrients in flow as long as possible [7].

The term 'bioeconomy' can be defined as exploration and exploitation of bio-resources [10]. McCormick \& Kautto [11] define bioeconomy as an economy where materials, chemicals and energy are developed and derived from renewable biological resources. In the Bioeconomy Strategy, the European Commission [12] has defined bioeconomy as an economy that relies on renewable biological resources (e.g. crops, forests and animals) and their conversion into food, feed, products, materials and energy. Bioeconomy includes agriculture, forestry, fisheries, food production, and pulp and paper production, as well as parts of the chemical, biotechnological and energy industries.

However, bioeconomy is not necessarily always sustainable; in fact, Loiseau et al. [13] have identified bioeconomy as a form of 'weak sustainability' due to its technological aspect, where a complete change in our consumption patterns is not regarded as necessary. On the other hand, CE is seen as supporting 'strong sustainability', based on its aim of closing the material loops. Furthermore, Allen [14] and Bezama [15] point out the importance of the circular aspect in bioeconomy. D'Amato et al. [16] state that CE principles should be integrated into bioeconomy in order to achieve bio-based CE. Bioeconomy and CE need each other in order to maximize their social and economic impacts [17]. In bio-based or bio CE, biological resources are managed and used in a way that the value of the materials is maintained at the highest utility in the economy for as long as possible [18]. In other words, bio-based CE is not considered circular only because it is based on renewable resources, but because it is designed to fulfil maximum efficiency while respecting the waste hierarchy [15], [16]. The waste hierarchy creates a prioritized order how to proceed with the management of waste, optimizing sustainability and resource efficiency [19]. As a conclusion, it can be said that the concepts of bioeconomy and circular economy have somewhat similar targets and they overlap to a certain degree [20].

An approach that enhances the concept of CE is industrial symbiosis, where industries create a network to share resources and minimize waste production [21], [22]. A company's waste can be harnessed by another company in a way that promotes the reuse of resources and enhances CE. Industrial symbiosis can also be bio-based, e.g. when biowaste is processed into biogas and upgraded to fuel, while the digested solid residual substitutes for organic fertilizers, contributing to soil fertility [23].

Due to the changed policy context and the introduction of CE, the EU Bioeconomy Strategy and action plan will be updated by the European Commission in 2018 [24]. Reflection on the relevance of the objectives and actions is needed on the EU level. The aim is to bring bioeconomy and CE closer to each other.

The term CE was presented in the EU context in 2011 through the Flagship Initiative under the Europe 2020 Strategy concerning a resource-efficient Europe [25]. The initiative stated that there was a need for a strategy to make the EU a 'circular economy'. In 2015, the European Commission released a CE package [9], proposing a series of actions towards CE. In order to achieve the goals of the CE package, it is essential that both national, regional and local authorities are enabling this transition. Also Loiseau et al. [13] and Geissdoerfer et al. [6] see that the shift towards strong sustainability and CE needs to have comprehensive support from governments. Consequently, CE requires efforts at different scale levels to reach a holistic approach: macro, meso and micro levels are all essential [26-29], [5]. The macro-level efforts refer to e.g. policy changes on national and regional levels, which will be discussed in this article. Meso level includes industrial networks and symbiosis between companies while micro level focuses on the companies and citizens as consumers. Figure 1 presents the $\mathrm{CE}$ framework on different levels. 


\section{Circular Economy - System Level Approach}

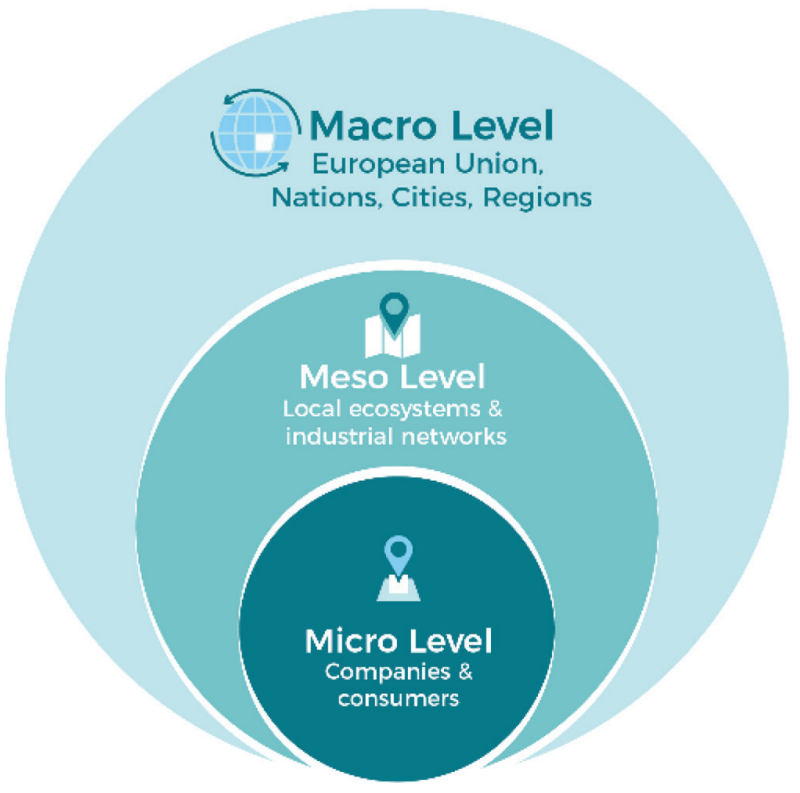

Figure 1: The system level approach to circular economy describes the actors on macro, meso, and micro levels (presented in [30]; based on e.g. [5], [26-29]).

\section{METHODS}

This paper presents the results of a qualitative assessment that was carried out in selected European countries: Finland, Spain, Slovakia, Greece, Romania and France. In these six countries, the most relevant national and regional strategies from the $\mathrm{CE}$ point of view were identified, compared and analyzed from the perspective of bio-based CE. The regions, which cooperate in the Interreg Europe financed project BIOREGIO [18], were selected to cover a wide socio-economical and geographical perspective of the European situation. The project boosts bio-based circular economy through a transfer of expertise about best available technologies and cooperation models, and runs from 2017 to 2021.

The data was gathered through a survey during November 2017. Project partners, in cooperation with their respective regional authorities, were responsible for identifying the most relevant strategies and replying to a set of questions based on them [31]. In addition, the case of Slovakia is presented more in detail bringing a quantitative aspect to the results.

\section{RESULTS ON THE NATIONAL LEVEL}

\subsection{CE in National strategies}

The questions of the survey concern the presence of CE and bio-based CE in the most relevant national and regional programs in order to analyze the situation of policy development 
in the country. Strategies reflect the status of implementation of an economic model, useful in giving an overview of the situation.

The increasing environmental awareness and push from the EU towards a more sustainable economic model, especially through the 2015 CE Package [9], are reflected on a strategic level in the partner nations. In all countries, except for Greece, the term CE exists in the main national level strategy [32].

The studied national strategies vary in the way they approach the CE objectives. Finland, for example, showed an integrative focus where different levels are addressed in the strategy. A national CE roadmap has been created, which sets the guidelines to achieve social, economic and environmental benefits such as increased jobs, a diversified market and a lower impact on the environment [33]. The road map aims at promoting the circulation of raw materials, prioritizing clean technology research and, ultimately, achieving self-sufficiency. The Finnish multidisciplinary approach integrates stakeholders into a model where technological and biological streams work together.

Spain, Slovakia, Romania and France share a common view regarding CE, as their national strategies are focused on waste management and raw material circulation [34]-[37]. Efficient use of resources defines the setting related to CE in these programs. The Spanish national waste management strategy aims to reduce $50 \%$ of domestic waste production and $70 \%$ of construction waste production by 2020 . There is an ambitious plan to promote the reduction of the end of life material in accordance with the CE model. In Slovakia, the government supports a transition to $\mathrm{CE}$ ensuring resource efficiency and energy efficiency, and reducing environmental impacts [34]. In the case of Romania, this should be achieved through waste prevention as it directly influences environmental impacts and production efficiency [36]. In the French strategy, CE is somewhat holistically mentioned as a strategic topic of its own, related to fighting waste but also developing product design and recycling [36].

On the other hand, CE is not yet included in the studied Greek national level strategy [32]. Also in Greece, waste management seems to be the main modus operandi the country starts from when implementing CE on a national scale. In this case, Greece centers its attention on the creation of a biowaste management scheme to improve sustainability and reduce direct pollution.

As noticed, waste management is the most common national approach that is linked to CE. However, this perspective is limiting the full potential of the multidisciplinary CE model.

\subsection{Bio-based CE in National strategies}

Bio-based CE or bio CE as a term is included only in the Finnish national program ("circular bioeconomy'). However, all other strategies have mentioned concepts regarding circularity of nutrients. Table 1 is an overview of National Strategies, showing the main findings regarding how $\mathrm{CE}$ and bio-based $\mathrm{CE}$ are presented in current national programs.

Finland has an integrated national CE roadmap in order to achieve a leading position in the world by 2025 [38]. In the roadmap, also bio-based CE is emphasized. The road map has a multidisciplinary approach where sustainable bioeconomy solutions are among the strategic goals, presenting the circularity of bioeconomy. There is a strong economic approach when dealing with bioeconomy, as it plans on reinforcing and utilizing the financial potential of bio-based materials. Bio-based CE is set to bring new usage to organic materials e.g. through sustainable food systems and recycling nutrients, as well as enhancing forest-based loops and producing bioenergy. 
Table 1: Overview of the studied national level strategies, November 2017 [31].

\begin{tabular}{|c|c|c|c|c|c|c|}
\hline \multicolumn{7}{|l|}{ National level } \\
\hline $\begin{array}{l}\text { National Strategy } \\
\text { name }\end{array}$ & $\begin{array}{l}\text { The Finnish Road- } \\
\text { map to a Circular } \\
\text { Economy }\end{array}$ & $\begin{array}{l}\text { Waste Manage- } \\
\text { ment State Plan } \\
\text { (PEMAR) }\end{array}$ & $\begin{array}{l}\text { The Waste Mana- } \\
\text { gement Program } \\
\text { of Slovak republic }\end{array}$ & $\begin{array}{l}\text { National Plan for } \\
\text { Waste Manage- } \\
\text { ment }\end{array}$ & $\begin{array}{l}\text { National Waste } \\
\text { Management } \\
\text { Strategy }\end{array}$ & $\begin{array}{l}\text { Law Relative to } \\
\text { EnergyTransition } \\
\text { for Green Growth }\end{array}$ \\
\hline Validity period & $2016-2025$ & $2016-2022$ & $2016-2020$ & $2015-2020$ & $2014-2020$ & $2015-2030$ \\
\hline $\begin{array}{l}\text { If no, specify other } \\
\text { corresponding terms }\end{array}$ & & & & $\begin{array}{l}\text { recycling, biowaste } \\
\text { disposal avoidance }\end{array}$ & & \\
\hline $\begin{array}{l}\text { Bio-based Circular } \\
\text { Economy included }\end{array}$ & Yes & No & No & No & No & No \\
\hline $\begin{array}{l}\text { Circularity of } \\
\text { nutrients mentioned }\end{array}$ & \begin{tabular}{l}
\multicolumn{1}{c}{ Yes } \\
sustainablc \\
food systems, \\
closing the loop
\end{tabular} & $\begin{array}{l}\quad \text { Yes } \\
\text { collccting and } \\
\text { processing } \\
\text { biowaste }\end{array}$ & \begin{tabular}{l}
$\quad$ Yes \\
\multicolumn{1}{c}{ recycling of } \\
biodegradable \\
waste
\end{tabular} & \begin{tabular}{l}
\multicolumn{1}{c|}{ Yes } \\
separate collection \\
and management \\
of biowaste \\
introduced
\end{tabular} & $\begin{array}{l}\quad \text { Yes } \\
\text { circulation of } \\
\text { organic waste } \\
\text { fractons }\end{array}$ & $\begin{array}{l}\text { Yes } \\
\text { reducing foodwaste, } \\
\text { separate collection } \\
\text { of biowaste }\end{array}$ \\
\hline $\begin{array}{l}\text { Status for new } \\
\text { National CE } \\
\text { Stratcgies }\end{array}$ & Existing (2016) & $\begin{array}{l}\text { Circular Spain } \\
\text { 2030: Spanish } \\
\text { Strategy for } \\
\text { Circular Economy } \\
\text { (Expected 2018) }\end{array}$ & $\begin{array}{l}\text { Greener Slovakia } \\
\text { - Strategy of the } \\
\text { Environmental } \\
\text { Policy of the } \\
\text { Slovak Republic } \\
\text { until 2030 } \\
\text { (Expected 2018) }\end{array}$ & $\begin{array}{l}\text { Greck National } \\
\text { Circular Economy } \\
\text { plan } \\
\text { (Expected 2018) }\end{array}$ & $\begin{array}{l}\text { Under } \\
\text { preparation }\end{array}$ & $\begin{array}{l}\text { French National } \\
\text { Circular Economy } \\
\text { Roadmap } \\
\text { (Expected 2018) }\end{array}$ \\
\hline
\end{tabular}

The Spanish, Slovakian, Romanian and French strategies point out the circulation of organic waste fractions mainly through a focus on collection and processing of biowaste. In addition, Greece, even if CE on a general level is not addressed, points out the circularity issues regarding biowaste. The Greek strategy mentions secondary materials as the bioapproach of the national waste management program in order to decrease greenhouse gas emissions. Also, the French and Romanian strategies mention the transition towards using renewable energy.

The parallelism in national policies among the studied countries emphasizes the necessity of a standardized bio-based CE approach, as waste management is the only focus observed in every studied nation. Thus, biowaste management is indeed the first step in the application of a sustainable bio-based economic model.

On another note, according to the study, developing renewable energy sources also seems to be one common interpretation of CE. Linking it to bio-based CE enhances bioenergy systems such as biogas plants.

\subsection{Upcoming National CE strategies}

Meanwhile, the countries are preparing new strategies to reinforce CE on a national level. Table 1 presents the situation of upcoming CE-related strategies. In this direction, Spain is planning to implement the Circular Spain 2030, focusing on bioeconomy enhancement emphasizing the internationalization of Spanish companies. Similarly, by 2030 Slovakia aims to establish a sustainable, circular industry framework within its borders. 'Greener Slovakia' focuses on the prevention of biodegradable waste generation as well as the enforcement of the 'polluters pay' principle, regulating waste management towards a circular economy. At the time of the study, France was developing a national CE roadmap. The plan was to set the steps towards a regenerative economic model, similar to the existing Finnish roadmap issued 
in 2016. The Greek government is also catching up by creating a financial plan aimed at providing the necessary resources and tools for the promotion of CE practices. The plan is a focused approach, which will shape the current status of the CE models in the country's industries.

In the case of Romania, the situation is quite different. In April 2017, the European Commission took Romania to the Court of Justice of the EU for failing to review and adopt its national waste management plan and waste prevention programme, in line with the objectives of the EU Waste Framework Directive [39] and the CE [37]. On the following day, the Ministry of the Environment published the first draft of the National Waste Management Plan for public consultation. At the time of the study, the situation was still in process.

\section{RESULTS ON THE REGIONAL LEVEL}

\subsection{CE in regional strategies}

At the time of the research, CE was mentioned as a term in the main strategic document in four out of six studied regions (Table 2). The regions from Finland, Spain, Romania and France have strategic documents, which all specify CE.

The Finnish Region of Päijät-Häme updated its regional strategy and program in 2017 [40]. It defines three focus areas of Smart Specialization, one of them being CE. In the regional context, CE mainly equals to material and energy efficiency and new solutions for bioeconomy. The CE part of the regional strategy is described in more detail in the Päijät-Häme road map towards CE [41]. The road map focuses on regional goals and presents examples of how to achieve them. The goals are related to bio-based CE, closing technical loops, new consumption models, sustainable energy solutions as well as piloting and demonstrating solutions. This regional CE road map is also recognized as a Good Practice, a valuable example to be shared through the European Policy Learning Platform [42].

In the region of Castilla-La Manca in Spain, the integrated waste management plan was updated in 2016. It includes the term CE as a guiding principle. The plan supports minimizing potential risks to human health and the environment through efficient waste management based on the principles of the CE [43].

The Smart Specialization Strategy of the Romanian region South Muntenia [44] mentions circular economy when describing bioeconomy. 'Bioeconomy, developing circular economy' is defined as a smart specialization field. The aim is to promote circularity in the bio sector, e.g. in the production of bio-fuels, ecological fertilizers and bio-composites. The other fields of smart specialization in South Muntenia are related to the food industry and smart localities, which are also fields with implications for CE. The strategy, set up in 2014, proactively referred to CE, even before the EU's CE package was launched. The strategy brings up to $\mathrm{CE}$ according to the EU Communication of the Commission from year 2011 [25].

The regional strategy of the Region of Pays de la Loire, the Performance Agreement for a Regional Dynamic about Waste and Circular Economy (CODREC) [45] strongly promotes $\mathrm{CE}$. In the agreement, the region took the position of a leading territory for waste management, $\mathrm{CE}$ and overall energy transition in France. It aims at developing the regional plan for prevention and management of waste and it has a chapter on CE.

The Program of Economic and Social Development of the Nitra Region in Slovakia [46] does not mention CE, nor does the Greek document Regional Waste Management Plan of 
Table 2: Overview of the studied regional level strategies, November 2017 [31].

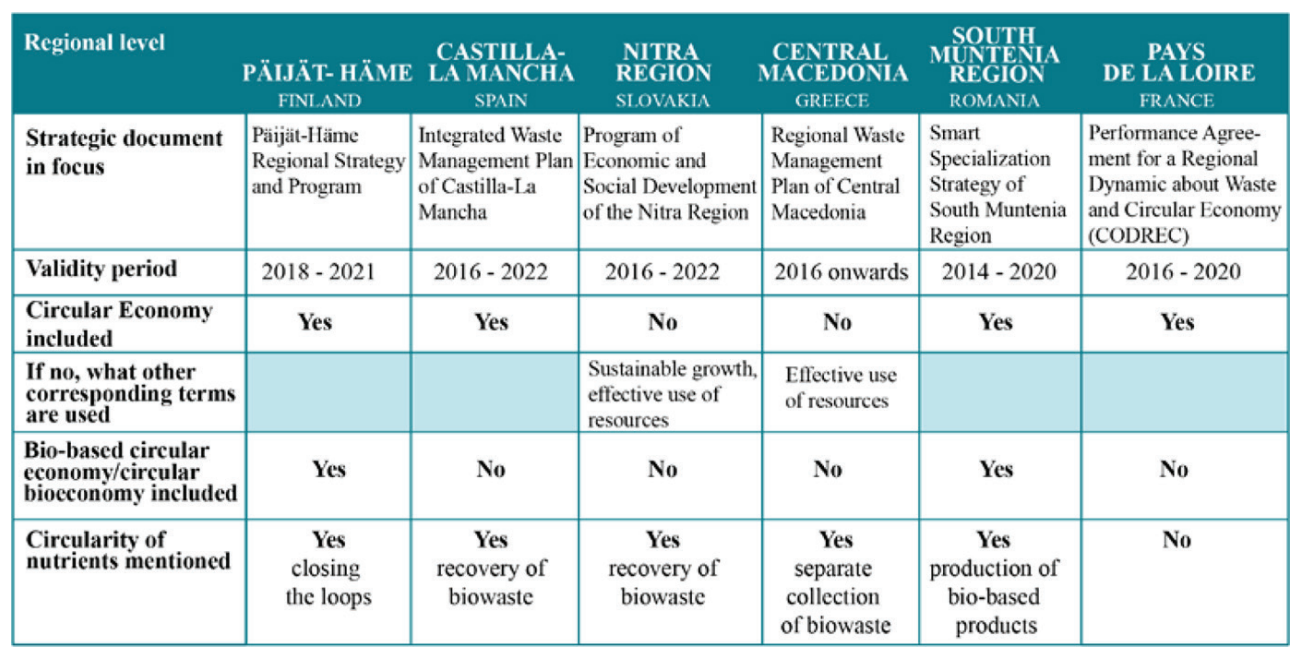

Central Macedonia [47], both issued in 2016. Nevertheless, they both refer to effective use of resources, which is linked to CE.

\subsection{Bio-based $\mathrm{CE}$ in regional strategies}

At the time of the study, the terms bio-based CE or bio circular economy only appear in the Finnish and Romanian regional strategies. In the Finnish region of Päijät-Häme, bio CE is seen as providing sustainable business. The strategy emphasizes closing of nutrient loops, supporting local food supply chains with less waste, and reducing the loss of raw materials. As mentioned before, the Romanian region of South Muntenia has a regional strategy that links bioeconomy closely with $\mathrm{CE}$. The focus is on an innovative use of biomass, e.g. the production of biofuels from biomass, animal manure and other by-products, production of organic fertilizers, as well as production of biomass products and by-products of biological processes.

However, the circularity or sustainability of bioresources is in some way brought up in almost all the other regional strategies studied. Developing the biowaste management, i.e. collection systems and processing patterns, seems to be the core starting point. Free-access platforms indicating the generated waste of any facility may present an opportunity for cooperation. Regional support and encouragement of such cooperation present a stepping-stone towards industrial symbiosis among facilities that use various biological streams and eventually facilitate the application of the CE concept on a larger scale.

The region of Nitra in Slovakia presents an example where bio-based CE is not mentioned in the regional strategy; however, waste management and bio-based circularity is promoted through small and large-scale instruments in the region. The key stakeholder Nitra SelfGoverning Region (NSGR) has, as a part of the regional strategy, introduced a unique instrument, which provides funding for small-scale local projects [48]. In 2017, an amount of EUR 549,479 was allocated for the instrument named LEADER NSK. The instrument reflects local needs through the 'bottom-up' principle. NSGR is currently the only Slovak 
region that financially supports local actions by a programme. Other Self-Governing Regions are aiming to introduce a similar programme.

In 2017, LEADER NSK funded following activities related to developing environmental activities, waste management and CE: Collection point for separated waste from the flat houses in the municipality Trávnica (EUR 3,500); Cleaning and treatment of surrounding water bodies and watercourses (EUR 1,000); Drainage of the public roads in Cedron-Nitrava (EUR 1,100); Collection point for waste in the municipality of Mudro ovo (EUR 2,680); Cleaning and treatment of rainwater ditches in the municipality of Podhorany (EUR 2,915); Educational project in the youth educational centre in municipality of Kuzmice 'Do not separate yourself and start to separate!' (EUR 1,530).

On the other hand, an example of a large-scale bio-based CE project in Nitra region is financed by the Operational Programme Environment: 'Separate Collection and Recovery of Biodegradable Waste' [49]. The project addresses waste management in municipalities in a unified way and it is based on the principles of circular bioeconomy. It also represents an example of a Good Practice published on the European Policy Learning Platform [50]. The project's total budget is EUR 10,192,582 (95\% EU funding).

\section{DISCUSSION AND CONCLUSIONS}

Since the data for this study was gathered, further development has taken place. In France, a new bioeconomy strategy was published in January 2018. It presents circularity as a strategic topic of its own. Also, a road map towards CE was published in April 2018, where biowaste management is presented as one of the goals. Furthermore, in Greece, the Hellenic Governmental Economic Policy Council approved the public policy framework for Circular Economy in March 2018, as being a key element of the country's Development Strategy update. The introduction of the $\mathrm{CE}$ aspect to the primary and secondary sector of economy is expected to create job opportunities, to increase small and medium-sized entrepreneurship and eventually upgrade social economy. In Slovakia, the government supports a transition towards CE. The existing raw material policy will be developed by identifying critical raw materials for the development of the Slovak economy. In Romania, the National Waste Management Plan was adopted by Government Decision in December 2017 together with the Waste Prevention Programme, and EU's infringement procedure was closed in March 2018. The situation is still under development as authorities are now developing a new strategy, which will revitalize the Romanian CE model, in accordance with the EU law. Figure 2 combines the situation of CE in national level strategies at the time of the study (November 2017) with the updated strategy development until June 2018.

Moreover, on the regional level, the update of the Slovak Program of Economic and Social Development of the Nitra Region was approved in June 2018. Sustainable CE is now stated in the program. In the future, there is further development expected also in other regions. Castilla-La Mancha will be the first region in Spain to have a law on CE. The law is expected during 2018. In Greece, the update of the Smart Specialization Strategy of the Region of Central Macedonia is expected to incorporate core elements of CE, also aiming at the circularity of bioeconomy. The update is estimated to be commenced during late 2018. In France, based on the national bioeconomy strategy, a regional biomass scheme will be adopted in Pays de la Loire in the beginning of 2019. It aims at directing the available biomass resources, including biowaste, for energy use.

To conclude, the comparison of the national policies of the countries shows that waste management is the key focus when addressing CE. Currently in Finland and France, and in 

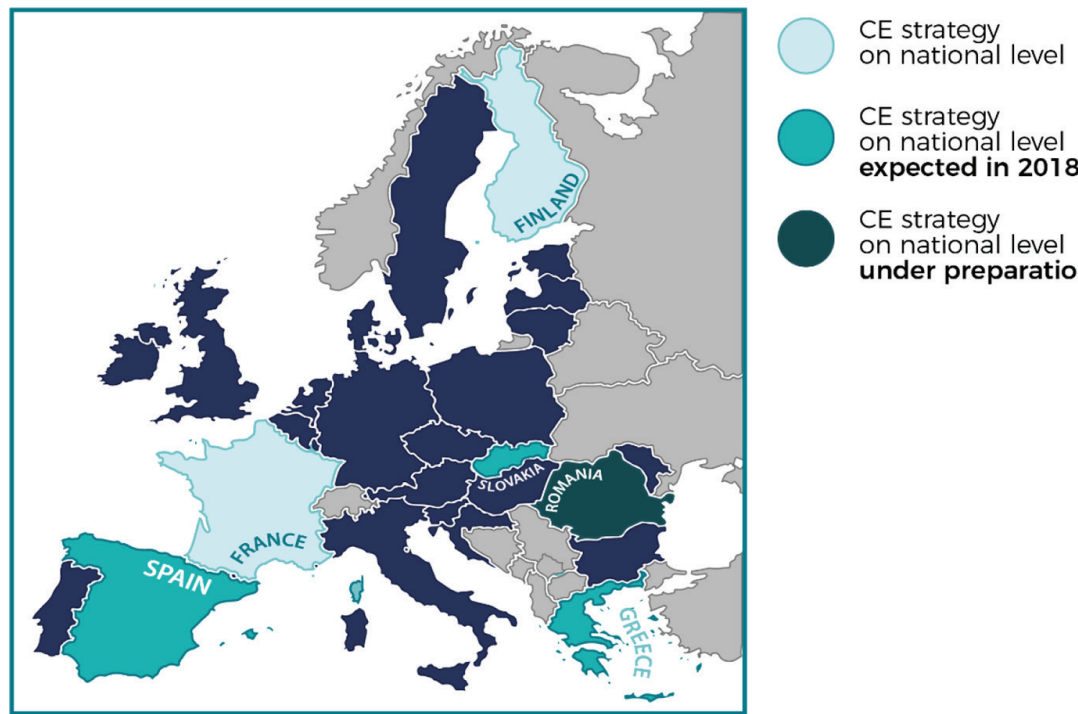

Figure 2: Map about the current situation of national level strategies, June 2018 [31].

the near future in Spain, Slovakia and Greece, there is a common approach to introduce CE as a multidisciplinary framework most likely enhancing the focus on the bio-based CE.

As Tables 1 and 2 present, the year of issue does not necessarily tell if CE is present or not. The Romanian strategies were issued in 2014, before the EU CE package, and they proactively already refer to CE. On the other hand, the Slovak and Greek regional strategies issued in 2016 do not mention the term.

On the national level, Finland and its Roadmap strategy is the only one that has included a focus on bio-based CE. However, in Spain, Slovakia, Greece, Romania and France bio-based $\mathrm{CE}$ is present in the analyzed strategies through a focus on biowaste management. They strive for the collection, recycling, and conversion of waste from biological streams in order to reduce environmental impacts. The focus on waste management is also evident in the funding instruments presented in the case of Slovakia.

Overall, it has been found that even if the bio-based CE is not mentioned as such, most countries address it in their strategies. Waste management, or in this case biowaste management, appears to be the main driver in the transition towards CE. However, the waste management focus in many cases limits the full potential of $\mathrm{CE}$ in biological streams. It should be understood that bio-based CE is more than separating, collecting and processing biowaste. The CE approach starts from reducing food waste. In striving towards CE on all levels, the authorities' role in pushing the development and setting up frameworks is essential. In this process, the macro-level actions in national and regional strategies play an important role. However, we suggest that the level division (micro, meso, macro) should be further discussed. In practice, the national and regional policies and their implementations differ from each other in scale and accuracy. Due to this, it would be helpful if the macro, meso and micro level divisions would be reconsidered, as the macro level including international, national, regional and local actions is seen as very broad in current literature. Nevertheless, in order for $\mathrm{CE}$ to become an integral part of national and regional policies, a 
more comprehensive understanding of the $\mathrm{CE}$ mechanisms needs to be achieved. At the same time, actions on different scale are needed in the regions in implementing the strategies.

\section{ACKNOWLEDGEMENTS}

The authors would like to thank the BIOREGIO partners and stakeholders for their effort and contribution to data collection.

\section{REFERENCES}

[1] Kahle, L.R. \& Gurel-Atay, E., Communicating Sustainability for the Green Economy, Routledge: UK, 2013.

[2] Bakari, M.E.K., The Dilemma of Sustainability in the Age of Globalization: A Quest for a Paradigm of Development, Lexington Books: New York, 2017.

[3] United Nations, GeneralAssembly, 2005 World Summit Outcome. ResolutionA/60/1, Online http://www.un.org/en/development/desa/population/migration/generalassembly/do cs/globalcompact/A_RES_60_1.pdf (accessed 8 June 2018).

[4] Severo, E.A., Ferrode Guimarães, J.C. \& Henri Dorion E.C., Cleaner production, social responsibility and eco-innovation: Generations' perception for a sustainable future. Journal of Cleaner Production, 186, pp. 91-103, 2018. https://doi.org/10.1016/j. jclepro.2018.03.129

[5] Ghisellini, P., Cialani, C. \& Ulgiati, S., A review on circular economy: The expected transition to a balanced interplay of environmental and economic systems. Journal of Cleaner Production, 114,pp. 11-32, 2016. https://doi.org/10.1016/j.jclepro.2015.09.007

[6] Geissdoerfer, M., Savaget, P., Bocken, N. M. \& Hultink, E.J., The Circular Economy - A new sustainability paradigm?. Journal of Cleaner Production, 143, pp. 757-768, 2017.

[7] Ellen MacArthur Foundation, Towards the Circular Economy: Economic and business rationale for an accelerated transition, 2012.

[8] Kirchherr, J., Reike, D. \& Hekkert, M., Conceptualizing the circular economy: An analysis of 114 definitions. Resources, Conservation and Recycling, 127, pp. 221-232, 2017. https://doi.org/10.1016/j.resconrec.2017.09.005

[9] The Euroepean Commission, Closing the loop - An EU action plan for the Circular Economy, COM/2015/0614, Online, https://eur-lex.europa.eu/legal-content/EN/TXT/? uri=CELEX\%3A52015DC0614 (accessed 23 May. 2018).

[10] Bugge, M., Hansen, T. \& Klitkou, A., What is bioeconomy? Sustainability, 8(7), pp. 1-22, 2016. https://doi.org/10.3390/su8070691

[11] McCormick, K. \& Kautto, N., The bioeconomy in Europe: an overview. Sustainability, 5(6), pp. 2589-2608, 2013. https://doi.org/10.3390/su5062589

[12] The European Commission, Innovating for Sustainable Growth: A Bioeconomy for Europe. COM/2012/060, Online https://eur-lex.europa.eu/legal-content/EN/TXT/? uri=OJ:C:2012:060:TOC (accessed 20 May. 2018).

[13] Loiseau, E., Saikku, L., Antikainen, R., Droste, N., Hansjürgens, B., Pitkänen, K., Leskinen, P., Kuikman, P. \& Thomsen, M., Green Economy and related concepts: An overview. Journal of Cleaner Production, 139, pp. 361-271, 2016. https://doi. org/10.1016/j.jclepro.2016.08.024

[14] Allen, B., A Step Further. The Bioeconomy, pp. 197-199, 2016.

[15] Bezama, A., Let us discuss how cascading can help implement the circular economy and the bio-economy strategies. Waste Management Res, 34, pp. 593-594, 2016. http:// dx.doi.org/10.1177/0734242X16657973 
[16] D’Amato, D., Droste, N., Allen, B., Kettunen, M., Lähtinen, K., Korhonen, J., Leskinen, P., Matthies, B.D. \& Toppinen, A., Green, circular, bio economy: a comparative analysis of sustainability avenues. Journal of Cleaner Production, 168, pp. 716-734, 2017. doi: org/10.1016/j.jclepro.2017.09.053

[17] Aguilar, A., Wohlgemuth, R. \& Twardowski, T., Perspectives on bioeconomy. New Biotechnology, 40, pp. 181-184, 2018. doi: 10.1016/j.nbt.2017.06.012

[18] BIOREGIO, Interreg Europe, https://www.interregeurope.eu/bioregio

[19] The European Commission, The role of waste-to-energy in the circular economy, COM/2017/034 final, Online https://eur-lex.europa.eu/legal-content/EN/TXT/?uri= CELEX\%3A52017DC0034 (accessed 20 May. 2018).

[20] Carus, M. \& Dammer, L., The "circular bioeconomy" - concepts, opportunities and limitations. Industrial Biotechnology, 14(2), Online https://www.coebbe.nl/en/content/what-biobased-economy-0 (accessed 6 February 2018). doi: 10.1089/ind.2018. 29121.mca

[21] Chertow, M.R., Industrial symbiosis: literature and taxonomy. Annual Review of Energy and the Environment, 25, pp. 313-337. 2000. doi: 10.1146/annurev.energy.25.1.313

[22] Costa, I., Massard, G. \& Agarwal, A., Waste management policies for industrial symbiosis development: case studies in European countries. Journal of Cleaner Production, 18(8), pp. 815-822, 2010. doi: 10.1016/j.jclepro.2009.12.019

[23] Interreg Europe. https://www.interregeurope.eu/ (accessed 20 May 2018).

[24] The European Commission, Review of the 2012 European Bioeconomy Strategy, Online https://ec.europa.eu/research/bioeconomy/pdf/review_of_2012_eu_bes.pdf\#view= fit\&pagemode=none (accessed 20 May 2018).

[25] The European Commission, A resource-efficient Europe - Flagship initiative under the Europe 2020 Strategy, COM/2011/0021 final, Online https://eur-lex.europa.eu/legalcontent/EN/TXT/HTML/?uri=CELEX:52011DC0021\&from=EN (accessed 20 May 2018).

[26] Yuan, Z.W., Bi, J. \& Moriguichi, Y., The Circular Economy: A New Development Strategy in China. Journal of Industrial Ecology, 10(1-2), pp. 4-8, 2006. doi: doi. org/10.1162/108819806775545321

[27] Geng, Y., Fu, J., Sarkis, J. \& Xue, B., Towards a national circular economy indicator system in China: an evaluation and critical analysis. Journal of Cleaner Production, 23(1), pp. 216-224, 2012. https://doi.org/10.1016/j.jclepro.2011.07.005

[28] Su, B., Heshmati, A. \& Geng, Y., A Review of the Circular Economy in China: Moving from Rhetoric to Implementation. Journal of Cleaner Production, 42, pp. 215-227, 2013. doi: 10.1016/j.jclepro.2012.11.020

[29] Geng, Y. \& Doberstein, B., Developing the circular economy in China: Challenges and opportunities for achieving 'leapfrog development'. The International Journal of Sustainable Development \& World Ecology, 15(3), pp. 231-239, 2008. doi:/10.3843/SusDev.15.3:6

[30] Manskinen, K., Foreword. Lahti Cleantech Annual Review 2016, Online http:// www.theseus.fi/bitstream/handle/10024/121322/LAMK_2016_24.pdf?sequence= 2\&isAllowed=y (accessed 20 April 2018).

[31] BIOREGIO, BIOREGIO policy overview.xls, 22.5.2018, Lahti University of Applied Sciences, Finland.

[32] Greek National Plan for Waste Management 2015-2020. In Greek, Online http://www. ypeka.gr/LinkClick.aspx ?fileticket=8rKEKVFO8G0\%3d\&tabid=238\&language $=$ el GR (accessed 20 May). 
[33] The Finnish Roadmap to a Circular Economy 2016-2025, Online https://media.sitra. fi/2017/02/24032659/Selvityksia121.pdf (accessed 20 April 2018).

[34] Waste Management State Plan PEMAR 2016-2020. In Spanish, Online https://www. boe.es/boe/dias/2015/12/12/pdfs/BOE-A-2015-13490.pdf (accessed 19 April 2018).

[35] The Waste Management Program of the Slovak Republic 2016-2020. In Slovak, Online http://www.minzp.sk/files/sekcia-enviromentalneho-hodnotenia-riadenia/odpadya-obaly/registre-a-zoznamy/poh-sr-2016-2020_vestnik.pdf (accessed 19 April 2018).

[36] Energy Transition for Green Growth Act 2015-2030. In French, Online https://www. legifrance.gouv.fr/affichTexte.do?cidTexte=JORFTEXT000031044385\&categorieLie $\mathrm{n}=\mathrm{id}$ (accessed 18 April 2018).

[37] Romanian NationalWaste Management Strategy 2014-2020.InRomanian, Onlinehttps:// legestart.ro/hg-nr-8702013-privind-aprobarea-strategiei-nationale-de-gestionare -a-deseurilor-2014-2020/ (accessed 19 April 2018).

[38] Finnish Ministry of Environment, Government's Goal: Finland is a Forerunner in the Circular Economy by 2025, Online http://www.ym.fi/enUS/The_environment/Circular_economy (accessed 6 Febraury 2018).

[39] The European Parliament, Directive 2008/98/EC of the European Parliament and of the Council of 19 November 2008 on Waste and Repealing Certain Directives, Online https://eur-lex.europa.eu/legal-content/EN/TXT/?uri=celex\%3A32008L0098 (accessed 20 May 2018).

[40] Päijät-Häme Regional Strategy and program 2018-2021, Regional Council of Päijät-Häme. 2017. In Finnish, Online http://www.paijat-hame.fi/wp-content/uploads/2018/01/ Maakuntastrategia_ja_ohjelma_2018-2021_nettiin.pdf (accessed 15 May 2018).

[41] Päijät-Häme Road Map: Towards Circular Economy in Finland, Online http://www. kohtikiertotaloutta.fi/english/ (accessed 15 May 2018).

[42] Interreg Europe. Good Practice: Utilisation of biowaste streams - bio-based industrial symbiosis, Online https://www.interregeurope.eu/policylearning/good-practices/ item/169/utilisation-of-biowaste-streams-bio-based-industrial-symbiosis/ (accessed 16 May 2018).

[43] Integrated waste management plan of Castilla-La Mancha 2016. In Spanish, Online http:// www.castillalamancha.es/sites/default/files/documentos/pdf/20170103/20161220pigr. pdf (accessed 16 May 2018).

[44] Smart Specialization Strategy of South Muntelia Region 2015. South Muntenia Regional Development Agency, Online http://www.onlines3.eu/wp-content/uploads/ RIS3_strategy_repository/RO_Sud_Muntenia_RIS3_eng.pdf (accessed 16 April 2018).

[45] Performance Agreement for a Regional Dynamic about Waste and Circular Economy (CODREC) 2016-2018. Pays de la Loire Region. In French, Online. http://docplayer. fr/52721161-Annexe-1-contrat-d-objectifs-pour-une-dynamique-regionale-dechets-eteconomie-circulaire-codrec.html (accessed 11 June 2018).

[46] Program of Economic and Social Development of Nitra Region in Slovakia 2016. Nitra Self-governing Region. In Slovak, Online https://www.unsk.sk/zobraz/sekciu/dokumenty-regionalneho-rozvoja (accessed 18 April 2018).

[47] Waste Management Plan of Central Macedonia 2016. Regional Council of Central Macedonia. In Greek, Online. https://fodsakm.gr/site/wp-content/uploads/2017/02/ PESDA_KM-1.pdf (accessed 18 May 2018).

[48] Subsidies from the budget of the Nitra Self-governing Region, from the "Programme to Support Integrated Rural Development LEADER NSK - Instrument 2, Activity 1.2 - Environmental Activities", based on Decree 3/2017 of Nitra Self-governing Region 
from 10.07.2017. In Slovak, Online http://original.unsk.sk/showdoc.do?docid=13220 (accessed 5 December 2018).

[49] Contract on irretrievable granting a financial contribution by ministry of Environment of Slovakia. In Slovak, Online https://www.crz.gov.sk/index.php?ID=186256\&l=sk (accessed 5 December 2018).

[50] Interreg Europe. Good Practice: Separate Collection and Recovery of Biodegradable Waste, Online https://www.interregeurope.eu/policylearning/good-practices/item/1557/ separate-collection-and-recovery-of-biodegradable-waste/ (accessed 5 December 2018). 